\title{
The influence of functional ingredients on the technological properties of water-swelling rubber sealing elements
}

\author{
(C) Evgeny N. Egorov, Nikolay F. Ushmarin, Konstantin V. Efimov, Sergey I. Sandalov, \\ Ivan S. Spiridonov, and Nikolay I. Koltsov* ${ }^{+}$ \\ Department of Physical Chemistry and Macromolecular Compounds. Chuvash State University \\ of I.N. Ulyanov. Moskovsky Ave., 15. Cheboksary, 428015. Chuvash Republic. Russia. \\ Phone: +7 (8352) 45-24-68. E-mail: koltsovni@mail.ru
}

\begin{abstract}
*Supervising author; ${ }^{+}$Corresponding author
Keywords: rubber mixtures, caoutchoucs, functional ingredients, technological properties, water-swelling sealing elements.
\end{abstract}

Abstract
The article investigated the influence of the nature and content of coutchoucs, sevilens, vulcanizing groups, fillers, plasticizers, ingredients of directional action on the technological properties (plasticity, ring modulus, density, start time of vulcanization, stickiness) of two rubber mixtures. These indicators characterize the processability of rubber compounds in the manufacture of products from them. The study was conducted in order to select the basis of rubber compounds for the manufacture of the outer and inner layers of waterswellable sealing elements (WSSE). It has been established that rubber compounds for the outer layer based on butadiene-nitrile BNKS-18AMN, isoprene SKI-3 and ethylene-propylene SKEPT-40 coutchoucs, as well as the inner layer of WSSE based on butadiene-nitrile BNKS-18AMN, butadiene methylstyrene SKMS30ARK and ethylene-propylene SKEPT-40 rubbers possess satisfactory technological properties. It was shown that these rubber mixtures which contain sevilen 11808-340, a vulcanizing group (sulfur + thiazole 2 MBS + guanid F), a combination of fillers (talc + grew $175+$ Karelite MK), petroleum resin Sibplast, directional ingredients (vermiculite + needle punched cloth "Oksipan"), hydrosorption additives (polyacrylamide AK $639+$ sodium polyacrylate), have improved technological properties. These rubber mixtures can be recommended as the basis for the manufacture of the outer and inner layers of water-swelling sealing elements for the oil and gas industry.

\section{References}

[1] A.K. Azizova, A.A. Gabbasova, R.I. Kateev, A.R. Iskhakov, R.R. Kadyrov. Development of waterswellable packers for seam separation and reduce the water inflow of oil-producing wells. Drilling and Oil Production. 2015. No.7-8. P.60-62. (russian)

[2] N.I. Koltsov, N.F. Ushmarin, A.E. Petrov, N.P. Petrov, N.N. Petrov, and S.M. Verhunov. Research of influence of technological additives on properties of rubbers on the basis of BNR new generation. Part 1. Vuhtazine RV/g-s. Butlerov Communications. 2010. Vol.19. No.2. C.79-86. ROI: jbc-02/10-19-2-79

[3] N.I. Koltsov, N.F. Ushmarin, L.G. Rogozhina, S.A. Issakova, A.V. Jarutkina, A.Y. Plehanova, and M.V. Kuzmin. Research of influence of technological additives on properties of rubbers on the basis of BNR new generation. Part 2. Elastid, oxsanoles and factice. Butlerov Communications. 2010. Vol.19. No.3. P.75-82. ROI: jbc-02/10-19-3-75

[4] N.I. Koltsov, N.F. Ushmarin, A.E. Petrov, N.P. Petrov, N.N. Petrov, and S.M. Verhunov. Research of influence of technological additives on properties of rubbers on the basis of BNR new generation. Part 3 . Novantox 8 PFDA. Butlerov Communications. 2010. Vol.21. No.10. P.22-28. ROI: jbc-02/10-21-9-22

[5] N.I. Koltsov, N.F. Ushmarin, L.G. Rogozhina, S.A. Issakova, A.V. Jarutkina, A.Y. Plehanova, and M.V. Kuzmin. Research of influence of technological additives on properties of rubbers on the basis of BNR new generation. Part 4. Powder stabilizers on a basis novantox 8 PFDA. Butlerov Communications. 2010. Vol.22. No.10. P.42-50. ROI: jbc-02/10-22-10-42

[6] N.I. Koltsov, N.F. Ushmarin, N.P. Petrova, Yu.V. Vasileva, A.V. Yarutkina, N.N. Petrova, A.Y. Plekhanova, and M.V. Kuzmin. Research of influence of technological additives on properties of rubbers on the basis of BNR new generation. Part 5. Fire retardants on the basis of trichloroethylphosphate combinations. Butlerov Communications. 2012. Vol.29. No.2. P.62-68. ROI: jbc-02/12-29-2-62 
THE INFLUENCE OF FUNCTIONAL INGREDIENTS ON THE TECHNOLOGICAL PROPERTIES...

[7] S.I. Sandalov, M.S. Reznikov, N.F. Ushmarin, N.I. Kol'tsov. Development of thermo-aggressive rubber for packer elements. Bulletin of the Kazan Technol. University. 2014. Vol.17. No.9. P.129-132. (russian)

[8] I.S. Spiridonov, N.F. Ushmarin, S.I. Sandalov, and N.I. Koltsov. The effect of hydrogenated butadiene-nitrile caoutchoucs on the properties of rubber for sealing elements. Butlerov Communications. 2017. Vol.50. No.4. P.45-49. DOI: 10.37952/ROI-jbc-01/17-50-4-45

[9] I.S. Spiridonov, N.F. Ushmarin, E.N. Egorov, and N.I. Koltsov. Effect of functional ingredients on the technological properties of rubber mixtures for sealing elements. Butlerov Communications. 2017. Vol.51. No.7. P.132-136. DOI: 10.37952/ROI-jbc-01/17-51-7-132

[10] I.S. Spiridonov, N.F. Ushmarin, S.I. Sandalov, E.N. Egorov, and N.I. Koltsov. Effect of functional ingredients on the physico-mechanical and operational properties of rubber mixtures for sealing elements. Butlerov Communications. 2018. Vol.53. No.1. P.153-157. DOI: 10.37952/ROI-jbc-01/1853-1-153

[11] I.S. Spiridonov, M.S. Illarionov, N.F. Ushmarin, S.I. Sandalov, N.I. Kol'tsov. Effect of ethylene-vinyl acetate copolymers on properties of rubber based on nitrile-butadiene rubber. Bulletin of the Higher Education Institutions. Series "Chemistry and Chemical Technology". 2018. Vol.61. No.8. P.51-57. (russian)

[12] I.S. Spiridonov, N.F. Ushmarin, S.I. Sandalov, E.N. Egorov, M.S. Illarionova, and N.I. Koltsov. Effect of functional ingredients on the tightness of rubber thermo-aging resistant sealing elements. Butlerov Communications. 2018. Vol.55. No.9. P.72-75. DOI: 10.37952/ROI-jbc-01/18-55-9-72

[13] N.F. Ushmarin, D.V. Pelipenko, K.V. Efimov, S.I. Sandalov, and N.I. Koltsov. The influence of copolymers of ethylene with vinyl acetate on the properties of oil-swelling rubbers. Butlerov Communications. 2018. Vol.53. No.2. P.134-139. DOI: 10.37952/ROI-jbc-01/18-53-2-134

[14] E.N. Egorov, N.F. Ushmarin, S.I. Sandalov, I.S. Spiridonov, and N.I. Koltsov. The influence of functional ingredients on the technological properties of oil swelling rubber sealing elements. Butlerov Communications. 2018. Vol.54. No.5. P.159-164. DOI: 10.37952/ROI-jbc-01/18-54-5-159

[15] E.N. Egorov, E.G. Efimovsky, N.F. Ushmarin, S.I. Sandalov, I.S. Spiridonov and N.I. Kol'tsov. The influence of functional ingredients on the physico-mechanical and operational properties of rubbers for the oil swelling sealing elements. Butlerov Communications. 2018. Vol.55. No.8. P.146-150. DOI: 10.37952/ROI-jbc-01/18-55-8-146

[16] E.N. Egorov, N.F. Ushmarin, S.I. Sandalov, I.S. Spiridonov, and N.I. Koltsov. The influence of functional ingredients on the technological properties of water-oil-swelling rubber sealing elements. Butlerov Communications. 2019. Vol.57. No.1. P.95-100. DOI: 10.37952/ROI-jbc-01/19-57-1-95

[17] E.N. Egorov, N.F. Ushmarin, S.I. Sandalov, I.S. Spiridonov, and N.I. Koltsov. The influence of functional ingredients on the physico-mechanical and operational properties of rubbers for water-oilswelling sealing elements. Butlerov Communications. 2019. Vol.57. No.2. P.68-73. DOI: 10.37952/ROI-jbc-01/19-57-2-68

[18] M.F. Galikhanov, D.M. Akhmedzyanova, N.R. Nikitin. Development and study of the properties of hydrosorption material based on a mixture of thermoplastic vulcanizate. Caoutchouc and Rubber. 2016. Vol.75. No.6. P.6-11. (russian)

[19] A.S. Zhirkeev, R.R. Kadyrov, R.Kh. Nizaev, D.K. Khasanova, R.A. Tabashnikov. Restricting the flow of water into the well using a polymer of company DRILLING SPECIALTIES. Bulletin of the TatNIPIneft. 2014. P.297-301. (russian)

[20] S.S. Lopatina, M.A. Vaniev, N.V. Sychev, D.V. Demidov, D.A. Nilidin, E.V. Bryuzgin. Development of water-oil-expanding rubbers intended for annular packers. Bulletin of the Volgograd State Technical University. 2017. No.11(206). P.91-96. (russian)

[21] A.V. Ivanova, N.F. Ushmarin, E.N. Egorov, S.I. Sandalov, N.I. Kol'tsov. Study of the effect of methylcellulose and sodium polyacrylate on the hydrosorption properties of rubber based on chloroprene rubber. Caoutchouc and Rubber. 2017. Vol.76. No.4. P.236-239. (russian)

[22] A.B. Livshits, A.Sh. Mingazov, N.F. Ushmarin, S.I. Sandalov, E.N. Egorov, L.P. Starukhin. Oilresistant frost resistant rubber compound. Patent 2633892, publ. 19.10.2017. Bulletin of Inventions No.29. (russian) 